肝区域間境界に位置する肝細胞癌に対する肝切除術

\begin{tabular}{|c|c|c|c|c|c|c|c|}
\hline \multicolumn{8}{|c|}{ 京都府立医科大学第 2 外科 } \\
\hline 塚本 & 賢治 & 鴻巣 & 寛 & 弘中 & 武 & 園山 & 輝久 \\
\hline 牧野 & 弘之 & 野中 & 雅彦 & 糸井 & 啓純 & 内藤 & 和世 \\
\hline 山岸 & 久- & 岡 & 隆宏 & & & & \\
\hline
\end{tabular}

\title{
PARTIAL HEPATECTOMY FOR HEPATOCELLULAR CARCINOMA LOCATED ON INTERSEGMENTAL BORDERS
}

\author{
Kenji TSUKAMOTO, Hiroshi KOHNOSU, Takeshi HIRONAKA, \\ Teruhisa SONOYAMA, Hiroyuki MAKINO, Masahiko NONAKA, \\ Hirosumi ITOI, Kazuyo NAITO, Hisakazu YAMAGISHI \\ and Takahiro OKA
}

The Second Department of Surgery, Kyoto Prefectural University, School of Medicine

\begin{abstract}
肝区域辺縁に位置する肝癌の切除法と残肝再発の関係について肝癌切除103例を対象として検討し た，区域境界に接する肝癌の切除肝では隣接区域転移は $6 \%$ ，被膜外浸潤は $64 \%$ に認められた。残肝 再発は，腫瘍辺縁を核出した（要）区域切除単独10例中 8 例に，担癌区域の（亜）区域切除に隣接区 域部分切除または（亜）区域切除を追加した11例中 3 例に認めた。 区域境界を越え隣接区域にまたが り存在する肝癌では, 切除肝の $24 \%$ に隣接区域転移が認められた。（亜)区域切除単独または隣接区域 部分切除の 7 例中 4 例が再発したが，隣接区域（覀）区域切除を追加した 8 例に再発はなかった。腫 瘍の存在位置に適した隣接区域の切除を追加すれば, 残肝再発を防止しうる可能性が示唆された。
\end{abstract}

卖引用語：肝細胞癌肝切除, 区域境界に存在する肝細胞癌, 肝細胞癌の残肝再発

\section{I. はじめに}

われわれは肝細胞癌切除の根治性を高めるために担 癌門脈枝を術早期に結禁し, 担癌門脈枝領域を系統的 に切除することを基本術式としてきだ'12).しかし，睡 瘍が（亚）区域の辺縁または複数の区域にまたがって 存在する場合には, 単なる(亜) 区域切除だけを行っ ても, 腫瘍辺縁の切離形態は核出術となり, その根治 性に疑問が残る。したがって，このような症例に対し ては, 何らかの局所的な拡大切除が必要である。われ

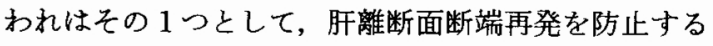
ために, 癌被膜外浸潤を取り残さない上うに肝切離面 より腫瘍辺縁までの肉眼的距離を $5 \mathrm{~mm}$ 以上確保する ことが必要であることを主張し，その成績について報 告した ${ }^{3)}$. しかし, 手術の実際で surgical margin の確

\footnotetext{
$<1989$ 年 7 月 10 日受理 $>$ 別刷請求先：塚本 賢治 $\overline{\mathbf{T}} 602$ 京都市上京区河原町通広小路上ル根井町 465 京都府立医科大学第 2 外科
}

保が困難なのは, 癌が肝深部のグリソン近傍に位置す るか，区域境界に存在する場合である。本研究では, 肝細胞癌症例の切除肝を病理組織学的に検索し, 区域 境界に存在する肝癌の隣接区域への肝内転移および被 膜外浸潤の有無について検討した。ささらに,この結果 之術後の残肝再発率お上び部位, 術後 (無再発) 生存 率との関連を検討し，区域境界に存在する肝癌に対す る適切な切除範囲の設定を試みた。

\section{II. 対象および方法}

1979年11月から1987年12月までの肝細胞癌切除例は 111例である.これらのらち絶対非治瘾切除 3 例, 切除 肝の病理組織学的検索が不十分な 5 例を除外し, 残る 103例を対象とした。

1. 癌の存在部位々切除方法との分類

対象を腫瘍と担癌区域境界面との位置関係 (Location；L）から, 次の 3 つに分類した.

$\mathrm{L} 1$ ：腫場が区域境界に接していない $(\mathrm{n}=36)$ 
L2：腫晹が区域境界に接している（n=36）

L3：腫瘍が区域境界を越え隣接区域にもまたがっ ている $(n=31)$

Lの分類は術前拈よび術中の超音波検查, computed tomography (CT)，血管造影および術中所見により総 合的に判定した. L2とL3の鑑別は, 主に血管造影所見

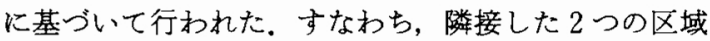
動脈枝が 1 つの腫瘍の栄養動脈となっている場合，ま たは，区域境界にあるが栄養動脈が特定できない場合 をL3とした。たと六腫瘍が境界線にまたがって存在し ていても，一区域動脈枝からだけ栄養されている場合 にはL2とした，L3の場合，主たる栄養動脈を分枝する 区域を主に占拠する区域とし，副となる栄養動脈の区 域を隣接区域とした。腫瘍の肉眼型が多結節型の場合 には，すべての結節のLの数の中で最も大きなそれを その症例の L 数とした。娘結節を有する症例では主腫 煌の L数を採用した。

対象を肝切除範囲 (resection；R）の設定方法によ り次の 3 つに分類した.

R1：(亜) 区域切除のみ（腫瘍辺縁の核出を含む）

$\mathrm{R} 2$ ：(严) 区域切除+隣接区域部分切除

R3：(亜) 区域切除十隣接区域（严）区域切除

ここでわれわれが（亜）区域切除と表現しているの は，担癌門脈の（亜）区域枝を結禁し，その支配領域 の肝蔵を切除する術式12)を示するのである。また，部 分切除とは門脈枝の支配領域とは関係なく肝切除を 行ったもので, 腫湟から肝切離面までの肉眼的距離を $5 \mathrm{~mm}$ 以上確保しえたものとした（図 1 ).

2. 切除肝の病理組織学的検討

腫場の存在部位別に担癌区域に隣接する区域への肝 内転移の頻度と, L2症例の組織学的被膜外浸潤の有無 について検討した。

3. 残肝再発とその肝内分布

術死, 術後 1 年以内無再発死亡, 門脈侵襲陽珄例, 肝部分切除例を除外した47例を対象とした，再発の診 断は，術後定期的な alphafetoprotein 值の測定，超音 波検查持よびCTにより行った。疑診例に対しては適 時血管造影を行い再発部位も含めて診断を確定した。 一部の例では剖検にて再発を確認した。再発の診断確 定時期は画像診断上再発を確認しらる最初の時期とし た。また，1989年1月末までに再発を確認できた症例 を再発例とした。累積無再発生存率と累積生存率は Kaplan-Meier 法により, 手術日より起算して算出し た，生存率の有意差の検定には，ログランク検定を用

因 1 L と R の分類

\section{Location}

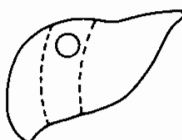

L1

Resection

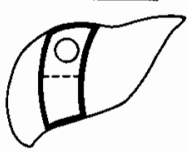

R1

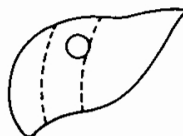

L 2

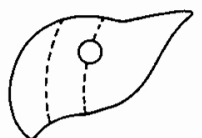

L 3

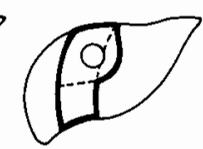

R2
R 3

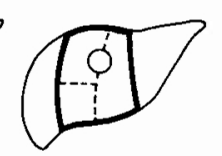

いた4、これとは別に門脈侵襲陽性22例の術後残肝再 発について検討した。組織学的な門脈侵襲の程度 (vp) は原発性肝癌取扱い規約らにしたがった。

\section{III. 結 果}

1. 切除肝の病理組織学的検討

L1の36例では R2以上の切除を行った症例はなく， 隣接区域の肝内転移については検索できなかった。

L2の36例中 R2以上の切除が行われたのは18例で あった。このらち切除標本に肝内転移が認められたの は 7 例であった。 7 例中 6 例は主腫痬存在（覀）区域 内にだけ肝内転移が認められ，隣接区域に肝内転移が 認められたのは18例中 $\mathrm{vp}_{2}$ の 1 例 (6\%) だけであっ た。門脈侵襲陰性11例の中で隣接区域に転移を認めた 症例はなかった。組織学的に被膜を有さない症例を被 膜外浸潤陽性例と乙て扱 5 , L2症例の組織学的被膜 外浸潤は36例中26例 (64\%) に認められた。

L3の31例中29例に R2以上の切除が行われた.この らち12例に肝内転移が認められた。主たる占扰区域だ けにそれが認められたのは 5 例で，隣接区域にそれが 認められたのは 7 例 (24\%) であった. 門脈侵襲陽性

表 1 担癌区域に隣接した区域の肝内転移 R2およびR3の切除47例を対象とした. 全症例

\begin{tabular}{c|c}
\hline & 隣接区域の肝内転移 \\
\hline L 2 & $1 / 18(6 \%)$ \\
L 3 & $7 / 29(24 \%)$ \\
\hline
\end{tabular}

\begin{tabular}{c|c}
\multicolumn{2}{|c|}{ 門脈唚襲陰性例 } \\
\hline & 隣接区域の肝内転移 \\
\hline L 2 & $0 / 11(0 \%)$ \\
L 3 & $4 / 18(22 \%)$ \\
\hline
\end{tabular}


表 2 LとRの組合せ別にみた残朋再発の頻度と部位

\begin{tabular}{|c|c|c|c|c|c|c|c|c|}
\hline \multirow{2}{*}{$\mathrm{L}$} & \multirow{2}{*}{$\mathrm{R}$} & \multirow{2}{*}{ 症例数 } & \multirow{2}{*}{ 残肝再発 } & \multicolumn{5}{|c|}{ 残肝再発部位 } \\
\hline & & & & 隣 & 闰 & 隣+泟 & 多 & その他 \\
\hline L 1 & R 1 & 11 & 5 & 1 & 1 & 1 & 1 & 1 \\
\hline L 2 & $\begin{array}{ll}\text { R } & 1 \\
\text { R } & 2 \\
\text { R } & 3\end{array}$ & $\begin{array}{r}10(6) \\
6(3) \\
5(1)\end{array}$ & $\begin{array}{l}8(5) \\
1(1) \\
2(0)\end{array}$ & $3(3)$ & $2(2)$ & & 2 & $\begin{array}{l}1 \\
1(1)\end{array}$ \\
\hline L 3 & $\begin{array}{ll}\text { R } & 1 \\
\text { R } & 2 \\
\text { R } & 3\end{array}$ & $\begin{array}{l}2 \\
5 \\
8\end{array}$ & $\begin{array}{l}1 \\
3 \\
0\end{array}$ & & & $\begin{array}{l}1 \\
1\end{array}$ & & 2 \\
\hline
\end{tabular}

隣：隣接区域のみ，问：同区域のみ，多：全肝多笺

（）は被膜外浸潤陽性例数

例を除外しても18例中 4 例 $(22 \%)$ に隣接区域転移が 認められた（表 1 ）。

2. 残肝再発とその肝内分布

L と R の組合せ別に術後の残肝再発の頻度をみる と, L2R1で10例中 8 例 $(80 \%)$ と高く, L3R3で 8 例中 0 例（ $0 \%$ ) と低かった。つざに，残肝に拈ける再発 部位を隣接区域のみ，同区域のみ，隣接区域十同区域 のみ，全肝多発性，その他に分類し検討した，L1では 再発パターンに特異なものはなかった. L2R1で被膜外 浸潤陽性の 6 例中 5 例が再発し，それらのすべてが隣 接または同区域再発であった。しかし，被膜外浸潤陰 性の L2R1执よびL2R2, L2R3の再発 6 例では隣接ま たは同区域再発はなかった。 L3では R1および R2の 4 例に再発があり，隣接区域十同区域 2 例，その他 2 例 と単純な再発形式は取らなかった, R3L3の8 例の5ち 切除肝に肝内転移が認められたのは 3 例（隣接区域肝 内転移は 2 例)であったが，残肝再発は 1 例も認めな かった（表 2 ).

$\mathrm{L}>\mathrm{R}$ 群 $(\mathrm{n}=17)$ と $\mathrm{L} \leqq \mathrm{R}$ 群 $(\mathrm{n}=30)$ に群別儿, 再 発率を比較した。 $\mathrm{L}>\mathrm{R}$ 群の再発は17例中12例（71\%） で， $\mathrm{L} \leqq \mathrm{R}$ 群の30例中 8 例 (27\%)より有意に高かった ( $\mathrm{p}<0.05 ， \chi^{2}$ 検定)，両群の背景因子を比較するため に, 腫瘍数, 尰瘍最大径, 術後観察期間沶よび進行度 （Stage）を比較したが，両群間に明らかな差は認めな かった（表 3 ).

門脈侵襲陽性22例を対象として, 術後残肝再発につ いて検討した. $\mathrm{vp}_{2}$ および $\mathrm{vp}_{3}$ の 6 例は全例術後 1 年以 内に残肝全体に多発性再発をきたした。 $\mathrm{vp}_{1}$ の16例で は $\mathrm{L}>\mathrm{R}, \mathrm{L}=\mathrm{R}$ の残肝再発率は，それぞれ 5 例中 4 例 $(80 \%) ， 9$ 例中 6 例 $(67 \%)$ であり，多発性再発の頻

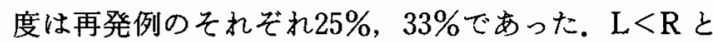
なった 2 例では術後48，13か月と観察期間は短いが，
表 $3 \mathrm{~L}>\mathrm{R}$ 群 $(\mathrm{n}=17)$ と $\mathrm{L} \leqq \mathrm{R}$ 群 $(\mathrm{n}=30)$ の背景因子

\begin{tabular}{|c|c|c|}
\hline & $L>R$ & $\mathrm{~L} \leqq \mathrm{R}$ \\
\hline 腫瘍数：1個 & 13 & 23 \\
\hline : 2 個以上 & 4 & 7 \\
\hline 腫場最大徍 (mm) & $44 \pm 4 \quad(23 \sim 80)$ & $40 \pm 7(8 \sim 180)$ \\
\hline 観察期間（月） & $35 \pm 4 \quad(13 \sim 66)$ & $36 \pm 4(13 \sim 77)$ \\
\hline 進行度 (Stage) & $\operatorname{II}(13), \operatorname{III}(3), \operatorname{IVA}(1)$ & $\mathrm{I}(6), \mathrm{II}(17), \mathrm{III}(7)$ \\
\hline
\end{tabular}

平均士標準誤差

表 4 門脈侵襲陽性例の L ， R と残肝再発 $\mathrm{vp}_{2}+\mathrm{vp}_{3}(\mathrm{n}=6)$

\begin{tabular}{l|l|l}
\hline & 再 発紊 & 多発珄再吪 \\
\hline $\mathrm{L}>\mathrm{R}$ & $3 / 3(100 \%)$ & $3(100 \%)$ \\
$\mathrm{L}=\mathrm{R}$ & $3 / 3(100 \%)$ & $3(100 \%)$ \\
\hline
\end{tabular}

\begin{tabular}{|c|c|c|}
\hline & 再 発 承 & 誃発性开登 \\
\hline$L>R$ & $4 / 5(80 \%)$ & $1(25 \%)$ \\
\hline $\mathrm{L}=\mathrm{R}$ & $6 / 9(67 \%)$ & $2(33 \%)$ \\
\hline$L<R$ & $0 / 2(0 \%)$ & $0(0 \%)$ \\
\hline
\end{tabular}

図 $2 \mathrm{~L}>\mathrm{R}$ 群と $\mathrm{L} \leqq \mathrm{R}$ 群の術後無再発生存率

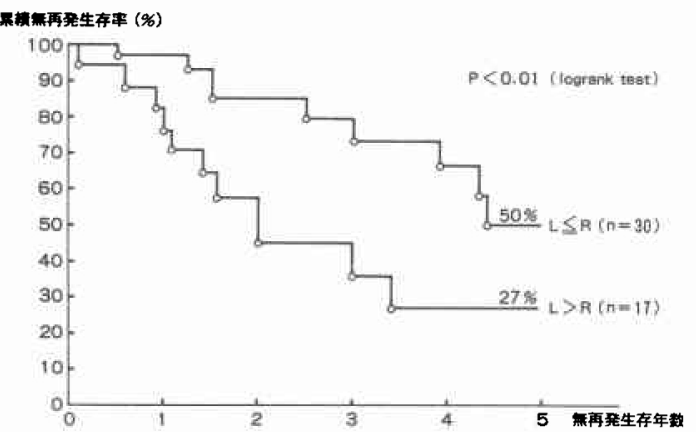


図 $3 \mathrm{~L}>\mathrm{R}$ 群と $\mathrm{L} \leqq \mathrm{R}$ 群の術後生存率

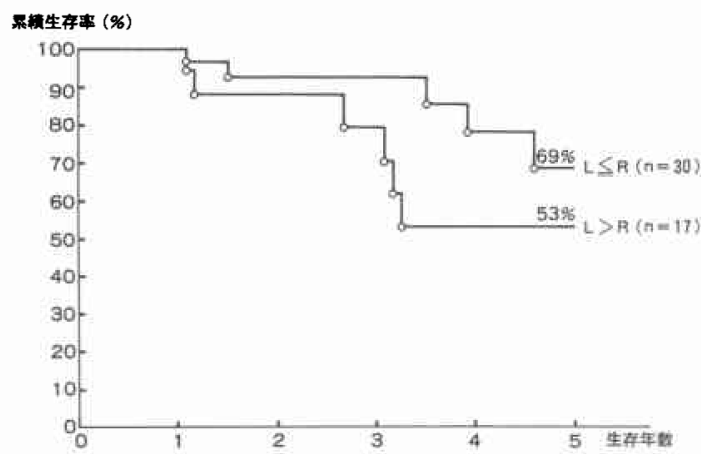

残肝再発は認めなかった（表 4).

3. L, R と累積（無再発）生存率

$\mathrm{L} \leqq \mathrm{R}$ 群の 3 年, 5 年の累積無再発生存率は, それぞ れ78\%，50\%で，L>R 群のそれらはそれぞれ45\%， $27 \%$ あった。 $\mathrm{L} \leqq \mathrm{R}$ 群の無再発生存期間は $\mathrm{L}>\mathrm{R}$ 群 のそれに比べて有意 $(\mathrm{p}<0.01$ ， ログランク検定）に長 かった（図 2).

$\mathrm{L} \leqq \mathrm{R}$ 群の 3 年, 5 年の累積生存率は, それぞれ 93\%，69\%で，L>R 群のそれらはそれぞれ78\%，53\% であった， $\mathrm{L} \leqq \mathrm{R}$ 群と $\mathrm{L}>\mathrm{R}$ 群との生存期間には有意 な差はなかった（図 3 ）。

\section{IV. 考察}

肝細胞癌の切除療法に拉いては, 術中の癌細胞散布 や微小な肝内転移の取り残しを防止するために, 術早 期に担癌門脈枝を結禁し，その支配領域を系統的に切 除することを基本としてきた。この考え方に沿った手 術を正確に行らために肝門処理法1やバルーンカテー テルを用いた系統的亜区域切除, さらに, 最近 3 年間 はグリソン処理を先行させた系統的垔区域切除 ${ }^{2} を$ 行ってきた。 しかし, 実際には, 今回の対象103例中67 例 $(65 \%)$ で稙瘍が区域辺縁に位置して㧍り，単なる 系統的(亜)区域切除だけでは,十分な surgical margin の確保は容易ではない.訮予備能の大きな症例であれ ば，2 区域以上の切除を行えば surgical marginの確 保が可能となるか子知れない, しかし, 自験肝細胞癌 の85\%は硬変を併存しており，実際に 2 区域以上の切 除が行われたのは25例に過ざない，したがって，かぎ られた肝実質切除量の範囲内で安全な surgical margin を確保するためには，系統的 (亜) 区域切除に部分 切除や亜区域切除をいかに有効に追加するかが問題で ある。

$\mathrm{L}$ と Rの分類に関しては，なるべく客観的な分類と
なるように努めたが，主観的な面が残されている点は 否めない，肝表面以外では明確な（亜）区域境界を確 認するの恃困難であるので，隣接区域再発と表現した 症例の中には，手術時に担癌区域の辺縁を取り残し， そこに癌が再発した同区域再発の症例が含まれている 可能性もある。しかし，実際の肝切除では，今回のよ らな分類を想定すると，癌の存在部位を明確に区別す ることが可能であり有用と考えている。また,“扇の要” に相当する肝の深部に存在する癌は，肝表面に位置す る癌に比べれば腫瘍径が小さくても区域境界に接する こととなり，この存在部位の分類は癌の肝表面からの 深度をも含めて表現するものと考えている。

切除肝の病理組馧学的結果からは, 腫冝が区域境界 に接しているとした L2では, 隣接区域への肝内転移は 門脈侵襲例を除けば認められなかった。したがって， 隣接区域のすべてを切除する必要はないであるう。乙 かし，L2症例の組織学的被膜外浸潤は64\%と高率であ り，腫瘍周辺をR1の切除で核出すれば，被膜外浸潤を 取り残す結果となる.L2症例の再発部位に関する検討 でも, L2R1の被膜外浸潤陽性例にかぎって隣接または 同区域といった局所再発的な再発形態をとったが，L2 $\mathrm{R} 1$ の被膜外浸潤陰性例やL2でも $\mathrm{R} 2$ 以上の切除を 行った症例では腫瘍の近傍に再発した症例がないこと もこの考光を裹づけるむのと考えられる.したがって， L2と判断された症例では, 癌の被膜外浸潤を含めて切 除できる部分切除を追加することが必要であろう。わ れわれは，腫瘍辺縁から肝切離面までの肉眼的距離を $5 \mathrm{~mm}$ 以上確保することが, 断端再発を防止する上で必 要であることを報告しており ${ }^{3)}$ ，現在ではL2の症例に 対しては系統的 (亜) 区域切除に肝実質を $5 \mathrm{~mm}$ 以上腫 瘍につける部分切除を付加することが必要と考えてい ๖.

腫湯が区域境界を越えるとしたL3症例の切除標本 病理組織学的所見では，隣接区域への肝内転移は $24 \%$ に認められた。 L3症例で隣接区域への転移が多い理由 としては，隣接区域の門脈末梢枝が腫瘍被膜内や周囲 の腫盼ドレナージ静脈の一部となっていることが予想 されるが証拠はない.しかし，L3R3の8例には現在ま で再発は認めていないことを考党ると，肝予備能が許 やば，L3に対しては腫瘍をグリソンの単位で包み込む よらに, 複数の（要）区域切除を横に連ねて切除する ことが再発防止には有用であるら。

門脈侵襲は肝癌切除後の残肝再発に深く関与する因 子とされているが6)7\}, 門脈侵襲陽性例でる, 再発防止 
のための “局所的抎大切除”に意義はあるのだろうか. 今回の検討からは, 少なくとも $\mathrm{vp}_{2}$ 㐨よび $\mathrm{vp}_{3}$ の症例 にかぎっては意義はないといわざるをえない。しかし， $\mathrm{vp}_{1}$ 症例の再発率は高いものの, 多発性再発の占める 割合は $\mathrm{vp}_{2}, \mathrm{vp}_{3}$ 症例に比べて低く, $\mathrm{L}<\mathrm{R}$ となるように 切除できれば局所的拡大切除による再発防止を期待し らる。

硬変併存肝癌では, 肝実質そのすのが結節性病変を 有するため，その術後再発の診断は容易ではない，今 回の検討ではこの点に留意し, 種々の画像診断や再発 疑診後の画像上の变化から間違いのないと判定された 症例だけを再発例とした。 $\mathrm{L} \leqq \mathrm{R}$ 群の無再発生存期間 が $\mathrm{L}>\mathrm{R}$ 群のそれよりる延長したことは，区域境界の 肝癌に対する “局所的払大切除”が再発防止に有効で あることを示す結果と考光ている。また， $\mathrm{L} \leqq \mathrm{R}$ 群の生 存期間が $L>R$ 群のそれより延長する傾向がみられる ものの有意な差とはならなかったのは，肝癌治療上の 特殊性にあるものと考支ている。すすなわち，肝癌では， たと六再発しても経動脈的塞栓療法やエタノール注入 療法に反応すれば再発後 3 年程度の生存はしばしば経 験することであり, 再発後の生存期間は手術以外の補 助療法により強く影響を受ける8゙たと考えている。

\section{V. おわりに}

肝細胞癌切除103例を対象として, 区域辺縁に位置す る肝細胞癌に対する適切な切除範囲設定を試みた。そ の結果,

1）区域境界に接する肝癌に対しては, 被膜外漫潤部 の取り残しを防止する意味で，担癌（亜）区域切除十
隣接区域部分切除を行う。

2）区域境界を越光る肝癌に対しては，隣接区域の肝 内転移の取り残しを防止する意味で，担癌（亜）区域 切除十隣接区域（亜）区域切除を行うことにより，術 後の残肝再発を防止しうる可能性が示唆された。

3）上述の考方方は，vp の症例には適応できるが， $\mathrm{vp}_{2}$ おび $\mathrm{vp}_{3}$ の症例には適応できないと考えられた。

本論文の要旨忚第33回日本消化器外科学会総会(東京)に て発表した。

\section{文 献}

1）弘中 武, 山谷和則, 鳰巣 寛注か：肝亜区域切除 術。旰門アブローチによる術式の試み。手術 37： $827-832,1983$

2）弘中 武, 園山輝久, 牧野弘之ほか：肝の系統的亚 区域切除術（肝右葉について）。外科治療 57 ： 203-212，1987

3）塚本賢治, 弘中 武, 鴻学 寛ほか：肝細胞澏切除 後の断端再発に関する臨床的検討. 日消外会誌 $22: 1093-1097,1989$

4）日本癌治療学会編：日本癌治療学会・生存率算出 規約. 金原出版，東京， 1985

5）日本肝癌研究会編：原発性肝癌取扱い規約. 第 2 版, 金原出版, 東京, 1987

6）園山輝久, 弘中 武, 岡 隆宏：門脈腫湯栓を有す る原発性肝細胞癌に対する外科治療の問題点一数 量化理論による再発要因の分析一。 日外会誌 $87: 1160-1163,1986$

7) 日本肝癌研究会：原発性肝癌に関する追跡調查 一第 8 報一。肝藏 $29: 1619-1626,1988$

8）岡本英三，山中若樹，加藤年啓浯加：肝切除術後再 発肝癌。肝・胆・膵 $15: 475-480,1987$ 